Review Article

\title{
A Study of Leptospirosis Epidemiology in Iran and Diagnostic Techniques for Human, Livestock and Environment Samples
}

Sona Rostampour Yasouri

Department of Microbiology, Falavarjan Branch

, Islamic Azad University, Isfahan, Iran

\section{Masoud Ghane iD}

Department of Microbiology, Tonekabon Branch, Islamic Azad University, Tonekabon, Iran

Monir Doudi

Department of Microbiology, Falavarjan Branch,

Islamic Azad University, Isfahan, Iran

Abolhasan Rezaei ID

Department of Genetic, Tonekabon Branch

, Islamic Azad University, Tonekabon, Iran

Nafiseh Sadat Naghavi iD

Department of Microbiology, Falavarjan Branch,

Islamic Azad University, Isfahan, Iran

Corresponding author: Masoud Ghane Email: Masoodghane@gmail.com Tel: +989111936373

Address: Department of Microbiology,

Tonekabon Branch, Islamic Azad University,

Tonekabon, Iran.

Received: $2019 / 09 / 22$

Revised: $2019 / 11 / 9$

Accepted: $2020 / 03 / 7$

\section{(c) (i) (8)}

This work is licensed under a Creative

Commons Attribution 4.0 License.

\begin{abstract}
Leptospirosis is a zoonotic disease with a high incidence rate in many parts of the world due to the presence of various hosts for the pathogenic Leptospira. Tropical, subtropical and humid regions are suitable for long-term survival of the bacterium. Because of the temperate and humid climate, northern areas of Iran are suitable for pathogenic Leptospira and outbreak of the disease. Therefore, identification of infected areas is important from a public health and economic point of view. Previous studies show that the incidence rate of leptospirosis is increasing every year. Therefore, accurate diagnosis, control and prevention of this disease seem necessary through vaccination and raising public awareness, especially among high-risk groups. Today, diagnostic methods including immunofluorescence assay, enzyme-linked immunosorbent assay, microscopic agglutination test (MAT) and polymerase chain reaction (PCR) are used to diagnose the leptospirosis. MAT is the gold standard test for the diagnosis of leptospirosis with extensive applications in Iran. Due to the importance of this disease and its high prevalence in recent years, the present study aimed to investigate the epidemiology and diagnosis of leptospirosis in Iran.
\end{abstract}

Keywords: Epidemiology, Leptospirosis, Diagnostic techniques, Iran 


\section{INTRODUCTION}

Leptospirosis is one of the most common zoonotic diseases in humans and livestock, with high incidence rates around the world (1). The prevalence of this life-threatening disease is higher in tropical, subtropical and wet regions (2). According to reports, this disease is more prevalent during summer (late spring) and autumn (3).

Leptospirosis is transmitted via direct or indirect contact with urine, blood or tissue of animals infected with pathogenic Leptospira. Several animal species are considered as natural hosts for Leptospira. The severity of this recurrent disease ranges from mild to acute, depending on the bacterium, its serotypes and host's immune system (3-6). The World Health Organization (WHO) has recognized leptospirosis as the second most commonly transmitted infection from livestock to humans $(7,8)$. In addition to public health concerns, the disease imposes significant financial burden due to the reduction of milk production, animal weight loss, livestock abortion, production of weak calves and decreased livestock fertility (9-12).

Evidence suggests that the rate of leptospirosis mortality is $5 \%$ to $30 \%$ around the world $(9,11)$. In developing countries, including Iran, the disease occurs more commonly among farmers, stockbreeders, slaughterhouse workers, butchers and fishermen during warm seasons. On the other hand, in developed countries, leisure activities, such as swimming, water skiing and other water sports as well as outdoor activities in contaminated areas, have been introduced as the main disease transmission routes (13). Port cities and towns near the Caspian Sea have a temperate and humid climate. In this region, many patients diagnosed with leptospirosis are hospitalized in emergency wards every year with a noticeable mortality rate (1). Generally, agricultural lands are ideal environments for rodents. Animals are the main reservoirs of pathogenic Leptospira in farms. Livestock are allowed to wander freely in farms for grazing. Therefore, humans and livestock are constantly exposed to the risk of leptospirosis. A set of conditions can lead to the spread of leptospirosis in Iran (14). With regards to the importance of this disease and its high incidence in recent years, the present study aimed to review the literature on leptospirosis in Iran.

\section{Data collection}

This study was conducted by reviewing several online databases including Google Scholar, PubMed, IranMedex, SID and Scopus. The searched keywords were "leptospirosis" and "Iran". All published data before the winter of 2018 were used to extract epidemiologic and diagnostic data.

\section{Epidemiology}

No accurate information is available regarding the incidence of leptospirosis. However, based on a recent report by the WHO, annual incidence of leptospirosis varies from 0.1-1 per 100,000 in temperate regions to $10-100$ per 100,000 in tropical and humid regions; it also occurs sporadically in industrialized countries (15). Generally, spread of the disease depends on factors, such as climate, population density and contact between the keeper host and random host (16). The most important hosts in rural and urban areas are rodents. If livestock come in contact with urine of infected rodents, the infection can spread to humans and other animals (17).

Different terms have been proposed to describe leptospirosis in different parts of the world with regard to the infection source, type of involved serovars, clinical findings in humans and livestock and place of occurrence (Table 1) $(18,19)$. Water is recognized as the most common source of transmission. In people with normal skin, infection may develop due to swimming in contaminated water, although skin abrasion is possibly the cause of infection. Transmission through sexual intercourse has been also reported (20). 
Table 1. Features of leptospiral disease

\begin{tabular}{|c|c|c|c|c|c|c|}
\hline \multirow{3}{*}{$\begin{array}{c}\text { Diffusion/ } \\
\text { spread } \\
\text { America, } \\
\text { Europe, Israel }\end{array}$} & \multirow[t]{2}{*}{ Clinical findings } & \multirow{2}{*}{$\begin{array}{c}\text { Disease in } \\
\text { humans }\end{array}$} & \multirow[t]{2}{*}{ Host } & \multirow{2}{*}{$\begin{array}{c}\text { Infection } \\
\text { source }\end{array}$} & \multicolumn{2}{|c|}{ eptospira interrogans } \\
\hline & & & & & Serovar & Serogroup \\
\hline & $\begin{array}{c}\text { Fever, an eruption in } \\
\text { the pretibial region } \\
\text {,jaundice }\end{array}$ & - & $\begin{array}{l}\text { Mouse } \\
\text { Pig } \\
\text { Skunk }\end{array}$ & Mouse & Ballum & Ballum \\
\hline $\begin{array}{l}\text { Through the } \\
\text { world }\end{array}$ & $\begin{array}{c}\text { Pseudo- influenza } \\
\text { disease, aseptic } \\
\text { meningitis }\end{array}$ & $\begin{array}{l}\text { Infectious } \\
\text { jaundice }\end{array}$ & $\begin{array}{l}\text { Human } \\
\text { Cattle } \\
\text { Dog } \\
\text { Swine }\end{array}$ & Dog's urine & Canicola & Canicola \\
\hline $\begin{array}{l}\text { Europe, } \\
\text { America, } \\
\text { Africa }\end{array}$ & $\begin{array}{l}\text { Fever, sweating, aseptic } \\
\text { meningitis }\end{array}$ & Marsh fever & $\begin{array}{l}\text { Cattle } \\
\text { Swine }\end{array}$ & $\begin{array}{l}\text { Rodents/ } \\
\text { water }\end{array}$ & Grippotyphosa & Grippotyphosa \\
\hline Japan, Europe & Fever, jaundice & $\begin{array}{l}\text { Seven-day } \\
\text { fever }\end{array}$ & $\begin{array}{l}\text { Cattle } \\
\text { Cattle } \\
\text { Human }\end{array}$ & $\begin{array}{l}\text { Rat/field } \\
\text { mouse }\end{array}$ & $\begin{array}{c}\text { Hardjo } \\
\text { Szwajizak } \\
\text { Georgia }\end{array}$ & Hebdomadis \\
\hline $\begin{array}{l}\text { All around the } \\
\text { world }\end{array}$ & $\begin{array}{l}\text { Jaundice, hemorrhage, } \\
\text { aseptic meningitis }\end{array}$ & Weil's disease & $\begin{array}{l}\text { Human } \\
\text { Cattle-dig } \\
\text { Swine }\end{array}$ & $\begin{array}{l}\text { Mouse's } \\
\text { urine/ } \\
\text { water }\end{array}$ & Icterohaemorrha-giae & Icterohaemorrha-giae \\
\hline $\begin{array}{l}\text { Europe, } \\
\text { America, } \\
\text { Australia }\end{array}$ & $\begin{array}{l}\text { Fever, sweating, aseptic } \\
\text { meningitis }\end{array}$ & $\begin{array}{l}\text { Swineherd's } \\
\text { disease }\end{array}$ & $\begin{array}{c}\text { Human } \\
\text { Cattle } \\
\text { Dog } \\
\text { Swine } \\
\text { Goat } \\
\text { Horse }\end{array}$ & $\begin{array}{l}\text { Pig/ } \\
\text { Cow }\end{array}$ & Pomona & Pomona \\
\hline
\end{tabular}

In a study conducted by Perret et al. in Chile, $70 \%$ of patients had positive history of contact with surface waters (21). In a study in Iran, $34.9 \%$ of patients had a history of contact with surface waters (22). In Costa Rica, the disease was transferred to humans through drinking contaminated river water (6). Leptospirosis is a seasonal disease, with the highest incidence during summer and autumn in temperate regions and during wet seasons in warm regions (23). Infection has been also reported during winter in areas where livestock are kept in enclosed spaces (16). Moreover, significant rainfall and flood increases the risk of contracting the disease (24).

In rural areas, outbreak of leptospirosis has been regularly observed due to torrential rainfall (25). According to a study in Thailand, the highest incidence rate of the disease was reported during wet seasons (late summer) (26). In urban areas, sewage and garbage waste is regarded as the main source of transmission, while water and environment can be contaminated with urine of infected mice (27). In these areas, the risk of infection is high in sewage workers as well as municipality workers but still not as high as farmers (28).

The prevalence of leptospirosis is limited to northern areas of Iran, especially the Guilan Province where the disease is endemic. It also occurs sporadically in neighboring provinces, including the Golestan (29), Tehran, Qom, Jahrom, Sabzevar and Ardabil provinces (30).
In recent years, other studies have reported the outbreak of the disease in Shiraz (31), Uremia (32), Zanjan (33), Hormozgan (34), Mashhad (35), Sistan and Baluchestan (36), Lorestan (37), Khuzestan and Tabriz (38). A major health concern is the long-term survival of many pathogenic species of Leptospira in water and wet soil, as they can enter the host body (human or livestock) through dermal abrasions (39).

Since simultaneous outbreak of leptospirosis in humans and livestock has not been studied in Iran, we aimed to investigate the prevalence of this infection and its common serovars in different provinces of Iran. The climate varies widely in different areas of Iran; therefore, surveying leptospirosis outbreak based on the isolated serovars is necessary in different areas of the country (Table 2).

\section{Diagnostic techniques}

Symptom-based diagnosis of leptospirosis is not feasible since the clinical signs and symptoms of this infection are similar to those of influenza and other febrile disease. If the disease is not diagnosed or treated promptly, it can progress into acute phase and cause serious and long-term damages. Therefore, alongside clinical examination, laboratory examinations are of great importance for the diagnosis of leptospirosis $(16,40)$. 
Table 2. Frequency of livestock and human serum samples suspected of leptospirosis based on the dominant servovars and categorization of Iranian provinces according to laboratory assessments by the microscopic agglutination test (MAT) technique.

\begin{tabular}{|c|c|c|c|c|c|c|c|c|c|c|c|c|}
\hline Sample & Province & $\begin{array}{l}\text { Autumnal } \\
\text { is } \\
\text { Number } \\
(\%)\end{array}$ & $\begin{array}{c}\text { Canicola } \\
\text { Number } \\
(\%)\end{array}$ & $\begin{array}{c}\text { Grippotyp } \\
\text { hosa } \\
\text { Number } \\
(\%)\end{array}$ & $\begin{array}{c}\text { Icterohaemorrha } \\
\text { giae } \\
\text { Number }(\%)\end{array}$ & $\begin{array}{c}\text { Pomona } \\
\text { Number } \\
(\%)\end{array}$ & $\begin{array}{c}\text { Sejroe } \\
\text { hardjo } \\
\text { Number } \\
(\%)\end{array}$ & $\begin{array}{c}\text { Sejroe } \\
\text { Sejroe } \\
\text { Number } \\
(\%)\end{array}$ & $\begin{array}{c}\text { Ballum } \\
\text { Numbe } \\
\text { r }(\%)\end{array}$ & $\begin{array}{c}\text { Australis } \\
\text { Number } \\
(\%)\end{array}$ & $\begin{array}{c}\text { Tarasso } \\
\text { vi } \\
\text { Numbe } \\
\text { r }(\%)\end{array}$ & Reference \\
\hline \multirow[t]{7}{*}{ Livestock } & Gilan & $5(17.8)$ & $1(3.5)$ & $16(21.4)$ & $8(57.1)$ & $0(0)$ & $14(50)$ & $5(17.8)$ & & & & 35 \\
\hline & $\begin{array}{c}\text { Mazandara } \\
\mathbf{n}\end{array}$ & $0(0)$ & $0(0)$ & $0(0)$ & $6(20)$ & $0(0)$ & $0(0)$ & $0(0)$ & & & & 35 \\
\hline & Ardabil & $1(2.3)$ & $3(7.1)$ & $0(0)$ & $0(0)$ & $0(0)$ & 26(61.9) & $0(0)$ & & & & 35 \\
\hline & Qom & $3(7.5)$ & $1(2.5)$ & $0(0)$ & $8(20)$ & $1(2.5)$ & $2(5)$ & $0(0)$ & & & & 35 \\
\hline & Hormozgan & $0(0)$ & $1(2.8)$ & $1(2.8)$ & $16(45.7)$ & $0(0)$ & $6(17.1)$ & $0(0)$ & & & & 35 \\
\hline & Uromia & & & $9(6.92)$ & $2(1.53)$ & $21(16.15)$ & $7(5.38)$ & $0(0)$ & & & & 39 \\
\hline & Tabriz & & $17(22.3)$ & $25(32.9)$ & $5(6.6)$ & $26(34.2)$ & $0(0)$ & $0(0)$ & $3(3.9)$ & & & 41 \\
\hline \multirow[t]{6}{*}{ Human } & Gilan & $1(2.4)$ & $1(2.4)$ & $1(2.4)$ & $5(12.1)$ & $1(2.4)$ & $2(4.8)$ & $2(4.8)$ & & & & 35 \\
\hline & $\begin{array}{c}\text { Mazandara } \\
\mathbf{n}\end{array}$ & $0(0)$ & $0(0)$ & $2(7.6)$ & $3(11.5)$ & $2(7.6)$ & $2(7.6)$ & $6(23.07)$ & & & & 35 \\
\hline & $\begin{array}{c}\text { Loresta } \\
\mathbf{n}\end{array}$ & & $22(36.67)$ & $38(63.33)$ & $0(0)$ & $0(0)$ & $0(0)$ & & & $0(0)$ & & 38 \\
\hline & Azarbaijan & $0(0)$ & $0(0)$ & $0(0)$ & $4(13.33)$ & $0(0)$ & $0(0)$ & & & & & 42 \\
\hline & $\begin{array}{c}\text { Mazandara } \\
\mathbf{n}\end{array}$ & $5(3.25)$ & $1(0.65)$ & $3(1.95)$ & $10(6.5)$ & $6(3.9)$ & $6(3.9)$ & $22(14.29)$ & $\begin{array}{c}26(16 . \\
87)\end{array}$ & 18(11.69) & $\begin{array}{c}21(13 . \\
64)\end{array}$ & 43 \\
\hline & Ahwaz & & $16(42.1)$ & $7(18.4)$ & $3(7.9)$ & $11(28.9)$ & $1(2.6)$ & & & & & 44 \\
\hline
\end{tabular}

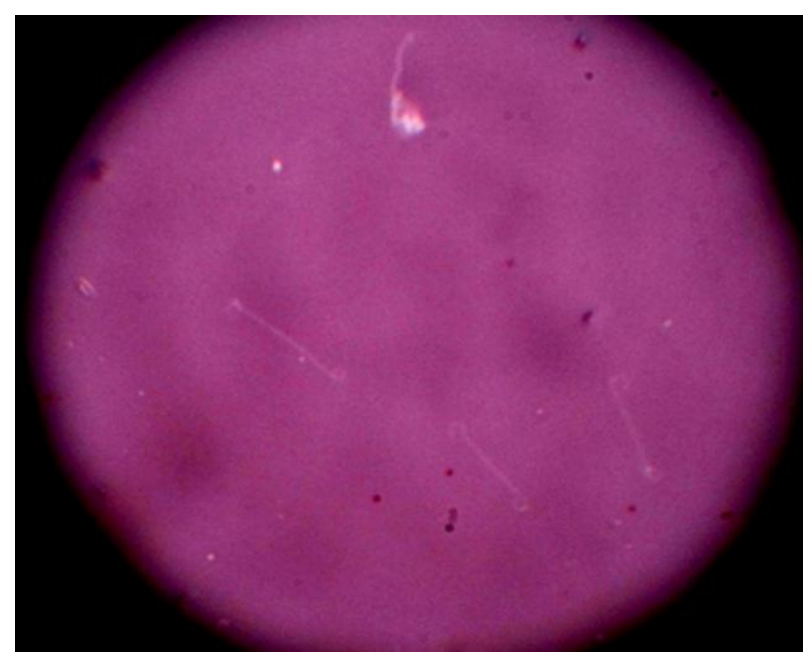

Figure 1. Photomicroscopy of Leptospira showing its morphology and hooked ends (photo was taken under 100× magnification) 
Dark-field microscopy of body fluids, such as blood, urine and cerebrospinal fluid can indicate the possibility of early diagnosis; however, sensitivity of this method is low. In case of blood samples, bacteria can be detected only within few days after the onset of the disease. Direct examination of blood samples via dark-field microscopy can lead to misdiagnosis given the sensitivity of $40.2 \%$ and specificity of $61.5 \%$ (42). Thus, sole use of this method is not recommended and other methods should be applied concomitantly. Direct investigation can be conducted through immunofluorescence staining, immunoperoxidase staining and silver staining, which are not used extensively due to limited availability and their relatively low sensitivity (43). Furthermore, Leptospira can be detected in tissues with the aid of histopathological staining and immunohistochemistry (20).

\section{Culture studies}

Leptospira can be isolated from clinical samples, including blood, cerebrospinal fluid, urine and tissue. Blood culture must be carried out immediately after the onset of disease and before antibiotic administration. Urine samples are also appropriate for the isolation of Leptospira during the Leptospirori phase, almost one week after the occurrence of disease (bacteria enter renal ducts and are excreted through urine. This phase can last long, during which the disease is transmitted. Blood and urine samples are inoculated into specific culture media and incubated at $30^{\circ} \mathrm{C}$. Cultures must be investigated regularly using dark-field microscopy (44).

It is known that pathogenic Leptospira grow slowly and their isolation through culture is very difficult and time-consuming. Considering the initial enrichment of pathogenic Leptospira in the EllinghausenMcCullough-Johnson-Harris (EMJH) medium, culturing in a solid EMJH medium earlier than two months does not produce positive results (one-month culture in liquid EMJH medium, transfer and inoculation of bacterium from the medium and re-culturing in solid EMJH for observing colonies). On the other hand, some Leptospira cannot be cultured; in other words, they are not capable of forming a colony (45). However, isolation and determination of their characteristics should be considered in epidemiological studies (44).

\section{Serological tests}

Detection of Leptospira antigens in clinical samples is not performed extensively. Recently, antigens have been identified in urine via dot-blot enzyme-linked immunosorbent assay (ELISA) or dot ELISA, using monoclonal antibodies against the unspecified $35-\mathrm{kDa}$ pathogenic Leptospira (46). These tests are used to identify antigens in the urine of individuals who are serum IgM negative. The majority of leptospirosis cases are diagnosed with the aid of serological tests. Antibodies can be detected within 5-7 days after the emergence of blood signs. The highest antibody titer is observed within the second week, and the infection can be diagnosed first using blood and then cerebrospinal fluid.

Microscopic agglutination test (MAT) is the gold standard serological test for diagnosis of leptospirosis as it identifies agglutinated antibodies in the patient's serum. In order to perform this test, the patient's serum is placed adjacent to a live bacterial suspension of various Leptospira serovars. The highest titer of the serum, which leads to the agglutination of $50 \%$ of bacteria, is determined using darkfield microscopy. Considering the difficulties in the diagnosis of agglutination in almost half of Leptospira bacteria, the final titer can be practically controlled by evaluating the presence of $50 \%$ of non-agglutinated free leptospires against the suspension. In various laboratories, different final titers (from 1:100 to 1:800 dilutions) are used for diagnosis, which can influence the final diagnosis.

On the other hand, MAT has several limitations that restrict its extensive application inclduing the need for a large spectrum of live leptospiral serovars to have a live antigen resource, presence of standard antiserums, dark-field microscopy, skilled laboratory technicians, serum samples causing delay in diagnosis and false negative results mainly due to lack of a Leptospira serotype(s) in the panel of bacterial cultures. In addition, due to the high rate of cross-reactions in various serogroups, especially in the acute phase, interpretation of the results is difficult (47). Moreover, using live antigens have health hazards for laboratory technicians. It should be noted that MAT cannot distinguish between agglutinated $\operatorname{IgM}$ and $\operatorname{IgG}$ antibodies, and the antigen panel must include the representative serovars of all subgroups as 
well as common serovars. Therefore, the WHO has suggested 19 serovars for 16 subgroups (44). Because of its low sensitivity, different samples including serum (a serum sample represents the acute phase and the convalescence period of the disease) are required for MAT to confirm the diagnosis. Therefore, rapid screening tests including ELISA, complement fixation test (CFT), dipstick ELISA, lateral flow test, indirect hemagglutination test and latex agglutination test have been taken into consideration for detection of antibodies in acute infections (48). Considering the complexity of MAT, different screening tests have been developed for detecting leptospiral antibodies during the infection. In this regard, CFT has been used extensively although it is not a standard method. This method is used for diagnosis in veterinary medicine based on which differences between various species can be determined (49). Accordingly, CFT has been replaced by ELISA methods. Since the IgM antibody is only produced at the end of the first week of disease onset, diagnosis is based on the identification of this antibody (50). If the first sample is collected at the beginning of the acute phase, IgM will be more sensitive than MAT. In specific dot-ELISA of $\operatorname{IgM}$ using nitrocellulose filters, a lower volume of reagents is needed. Due to advances in ELISA, this method can identify IgM and IgA by using fabric polyester resin instead of nitrocellulose. Although this test is a simple, fast and inexpensive approach, which can be used in laboratories with limited facilities, its results must be confirmed by MAT due to the possibility of false positives. Dipstick dotELISA is conducted using commercial kits, which show similar sensitivity to common IgM-ELISA test (43).

Use of LipL32 recombinant antigen in ELISA is a sensitive, specific and accurate approach for detection of anti-Leptospira antibody in serum samples (51). On the other hand, serological tests are the most commonly used methods for laboratory diagnosis of leptospirosis. However, considering the delayed emergence of specific Leptospira antibodies in the blood, they cannot be used for rapid diagnosis in the first week or in the acute phase of the disease; these problems can be eliminated by using molecular diagnostic methods.

\section{DNA detection}

In recent decades, detection of Leptospira DNA using polymerase chain reaction (PCR) assay has been used for early diagnosis of leptospirosis. Sensitivity of this method in blood samples ranges from $28 \%$ to $98 \%$ in severe cases (52). The test also has a specificity of $>90 \%$, which is higher than that of MAT (53). Numerous genes, such as $\sec Y$, rrs, Fla13, and rrl as well as the LA3521 genomic position in the serovar of Leptospira interrogans are targets for PCR diagnosis (54). Leptospira can be reproduced in the blood, urine, cerebrospinal fluid, aqueous humor and tissues. Recently, real-time PCR has been introduced as a fast and sensitive approach for detecting Leptospira DNA. This method can identify rrs, LigA, LigB, lipL32, seeY and gyrB genes as well as LA0322 genomic position in the serovars of $L$. interrogans using Taqman probes or fluorescence SYBR green stain. Both standard PCR and real-time PCR are applied for early diagnosis when antibodies are not produced (55).

Recently, loop-mediated isothermal amplification (LAMP) has been used for identification of pathogenic Leptospira species. Unlike PCR, this method can duplicate the sequence of target DNA in isothermal conditions with high specificity and efficiency for almost one hour. This method does not require a thermal cycler in order to establish a thermal gradient. The results of LAMP can be assessed by naked eye (56). This method has been implemented to detect Leptospira DNA in kidney of mice; however, its sensitivity and specificity have not been evaluated in clinical human samples (57).

\section{DISCUSSION}

Leptospirosis is a common multifactorial disease in Iran, particularly in the northern areas. Without laboratory tests, accurate clinical diagnosis of leptospirosis can be challenging (37). In order to diagnose this disease, various methods including MAT, ELISA, fluorescent antibody test, culture and PCR have been introduced (45). Serological tests, including MAT, which is regarded as the gold standard test in epidemiological studies, are among the most common diagnostic approaches (58).

Studies on leptospirosis rely on three principles: humans, livestock and environment (59). 
Studies carried out in Iran and other countries suggest the presence of serum contamination with Leptospira in livestock; however, the results are controversial regarding the frequency and type of involved serotypes (Table 2). In a study by Yasouri et al. (2013), the frequency of pathogenic Leptospira was $33.04 \%$ among 115 water, soil and animal feces samples collected from rice fields of Tonekabon, northern Iran (60).

In Italy, contaminated water or soil $(81.8 \%)$, followed by animals and animal urine (18.2\%) were identified as the main source of infection. Moreover, running water $(51.2 \%)$ and stagnant water $(27.9 \%)$ were the most common sources of infection (61).

The most common serotypes were Ballum, Sejroe, Tarassovi and Australis in a study in the Mazandaran Province, Iran. House mice and rats were the reservoir hosts of Ballum serogroup, while farm animals were the hosts of Sejroe, Australis, and Tarassovi serogroups. In another serological investigation, antibodies against L. interrogans serogroups Icterohaemorrhagiae, Grippotyphosa and Canicola were detected in suspected cow flocks in the Mazandaran Province, Iran (62). These serotypes were less common in humans. Furthermore, Ebrahimi et al. reported the rate of Leptospira serotypes to be $48.5 \%$ in tribal areas of west central Iran. The highest rate of incidence was related to serotype Hardjo (54.12\%), followed by Pomona, Icterohaemorrhagiae and Canicola (63).

The rate of leptospirosis differs widely depending on the country and serotypes. For instance, Autumnalis was found as the dominant serotype in Nadu, India (64). In Brazil, Copenhageni from the Icterohaemorrhagiae serogroup was reported as the predominant serotype in an epidemic area of Salvador (65). In Italy, Icterohaemorrhagiae, Poi, Copenhageni and Bratislava were identified as the most abundant serotypes (61).

Fakheri et al. reported that the most important contributing factors for leptospirosis are the occupational exposure of farmers, livestock breeders, slaughterhouse workers, hunters and fishers, contact with infected animals and recreational activities, such as swimming, boating and skiing (66). In industrialized countries, leptospirosis occurs in a singlecaught format and is mostly related to recreational boating, swimming in rivers and hunting. In addition, leptospirosis has been reported in mine workers, sewage workers and fishers $(67,68)$. In this regard, in a study by Zakeri et al., contact with animals, contaminated water and farming were reported as the main risk factors for leptospirosis (69).

\section{CONCLUSION}

Since Leptospira have multiple specific hosts, eradication of leptospirosis can be challenging. Leptospirosis is known to resemble influenza and cannot be easily diagnosed due to variability of clinical signs. The disease is underreported due to the shortage of diagnostic samples and difficulties in diagnosing and differentiating the clinical signs of the disease from other endemic diseases. Today, there is no reliable reference/resource for estimation of leptospirosis in humans. A major problem in evaluating the occurrence of leptospirosis in humans is identification of its sources. Therefore, further studies are required to investigate the sensitivity of leptospirosis tests. Despite the economic burden of leptospirosis and the associated public health concerns, this disease has not been taken seriously in Iran. To control this disease, it is important to educate people about the modes of transmission and encourage the use of protective equipment among rice farmers and livestock breeders. It is also essential to determine prevalence and dominant serovars/serogroups in different areas, and provide polyvalent vaccines.

\section{CONFLICT OF INTEREST}

The authors declare that there is no conflict of interest.

\section{REFERENCES}

1.Honarmand H. A decade, the incidence of leptospirosis in Guilan. Iran J Infect Dis. 2009; 47: 47-53.

2.World Health Organization. Human leptospirosis: Guidance for diagnosis, surveillance and control. Translate by Khaki P, Moradi Bidhendi S, Moradi Garavand M [Persian]. $1^{\text {st }}$ ed. Tehran: Alavi Publication; 2003. 1-37.

3.Zavitsanou A, Babatsikou F. Leptospirosis: epidemiology and preventive measure. Health Sci J. 2008; 2(2): 75-82.

4.Sakhaee E, Abdollahpour G, Bolourchi M, Sattari Tabrizi S. Comparison between microscopic agglutination test (MAT) and enzyme-linked immunosorbent assay (ELISA) for detection of leptospiral antibodies in cattle. Comp Clin Path. 2009; 19(1): 59. doi:10.1007/s00580-009-0907-7.

5.Asuthkar S, Velineni S, Stadlmann J, Altmann F, Sritharan M. Expression and characterization of an iron-regulated heminbinding protein, HbpA, from Leptospira interrogans serovar Lai. Infect Immun. 2007; 75(9): 4582-91. doi:10.1128/IAI.00324-07.

6.Trevejo RT, Rigau-Perez JG, Ashford DA, McClure EM, Jarquin-Gonzalez C, Amador JJ, et al. Epidemic leptospirosis associated with pulmonary hemorrhage-Nicaragua, 1995. J Infect Dis. 1998; 178(5): 1457-63. doi:10.1086/314424. 
7.Lin YP, Chang YF. The C-terminal variable domain of LigB from Leptospira mediates binding to fibronectin. J Vet Sci. 2008; 9(2): 133-44. doi:10.4142/jvs.2008.9.2.133.

8.Sejvar J, Bancroft E, Winthrop K, Bettinger J, Bajani M, Bragg $\mathrm{S}$, et al. Leptospirosis in "Eco-Challenge" athletes, Malaysian Borneo, 2000. Emerg Infect Dis. 2003; 9(6): 702-7. doi:10.3201/eid0906.020751.

9.Babamahmoodi F, Salmani Mojaveri M, Babamahmoodi AR. Seroepidemiology of leptospirosis in workers of high risk occupation in Mazandaran province-Iran 2007-2008. J Mazandaran Univ Med Sci. 2009; 19(73): 10-5. [Persian]

10.Wong-Ekkabut J, Chadsuthi S, Triampo W, Doungchawee Galayanee TD, Krittanai C. Leptospirosis research: Response of pathogenic spirochete to ultraviolet-A irradiation. Afr $\mathbf{J}$ Biotechnol. 2009; 8: 3341-52.

11.Babamahmoudi F. Human leptospirosis. Tehran: Agah press. 2008.

12.McBride AJ, Athanazio DA, Reis MG, Ko AI. Leptospirosis. Curr Opin Infect Dis. 2005; 18(5): 376-86. doi:10.1097/01.qco.0000178824.05715.2c

13. Aliyan SH, Babamahmoudi F, Najafi N, Qasemian R, Teymouri S, Shahbaznezhad L. Clinical and para clinical findings of leptospirosis in Mazandaran, June-September 2004. J Mazandaran Univ Med Sci. 2006; 16(53): 78-85. [Persian]

14.Ghane M, Rostampour YS. Isolation and identification of pathogenic and saprophytic Leptospira spp. From the rice fields of Tonekabon township using culture and PCR technique. Ann Biolog Res. 2013; 4(11): 123-8.

15.Soltani PR. Leptospirosis in pregnancy. J Nurs Sch Guilan. 2008; 19(61): 42-37. [Persian]

16.Tabatabayi AH, Firouzi R. Disease of animal due to bacteria. Tehran University Press; 2001; 431-45.

17.Jori F, Galvez H, Mendoza P, Cespedes M, Mayor P. Monitoring of leptospirosis seroprevalence in a colony of captive collared peccaries (Tayassu tajacu) from the Peruvian Amazon. Res Vet Sci. 2009; 86(3): 383-7. doi:10.1016/j.rvsc.2008.09.009.

18.Brooks G, Carroll KC, Butel J, Morse S. Jawetz melnick and adelbergs medical microbiology. Translate by Rahimi MK, Athari A, et al. [Persian]. 23 $3^{\text {rd }}$ ed. Tehran: Aeej Publication; 2005; 538-41.

19.Joklik WK, Willett HP, Amos DB, Wilfert CM. Zinser microbiology. Tehran: Aeej Publication. 2003; 457-60.

20.Levett PN. Leptospirosis. Clin Microbiol Rev. 2001; 14(2): 296-326. doi:10.1128/CMR.14.2.296-326.2001.

21.Perret PC, Abarca VK, Dabanch PJ, Solari GV, Garcia CP, Carrasco LS, et al. Risk factors and frequency of positive antibodies for leptospirosis in a sub urban population near Santiago. Rev Med Chil. 2005; 133(4): 426-31. doi:/S003498872005000400005.

22.Honarmand HR, Mansour-Ghanaee F, Eshraghi S, Khorramizade MR, Abdollahpour GR. The epidemiology of leptospirosis in Guilan provice - 2003. J Gorgan Uni Med Sci. 2005; 7: 52-6. [Persian]

23.Levett PN. Leptospirosis: A forgotten zoonosis? Clin Appl Immunol Rev. 2004; 4(6): 435-48. doi:10.1016/j.cair.2004.08.001

24.Lau CL, Smythe LD, Craig SB, Weinstein P. Climate change, flooding, urbanisation and leptospirosis: Fuelling the fire? Trans R Soc Trop Med Hyg. 2010; 104(10): 631-8. doi:10.1016/j.trstmh.2010.07.002.

25.Barkin RM, Guckian JC, Glosser JW. Infection by leptospira ballum: A laboratory-associated case. South Med J. 1974; 67(2): 155 passim. doi:10.1097/00007611-197402000-00007.

26. Tangkanakul W, Smits HL, Jatanasen S, Ashford DA. Leptospirosis: An emerging health problem in Thailand. Southeast Asian J Trop Med Public Health. 2005; 36(2): 281-8.
27.Ganoza CA, Matthias MA, Collins-Richards D, Brouwer KC, Cunningham CB, Segura ER, et al. Determining risk for severe leptospirosis by molecular analysis of environmental surface waters for pathogenic Leptospira. PLoS Med. 2006; 3(8): e308. doi:10.1371/journal.pmed.0030308.

28.Haake DA. Molecular epidemiology of leptospirosis in the Amazon. PLoS Med. 2006; 3(8): e302. doi:10.1371/journal.pmed.0030302.

29.Golsha R, Khodabakhshi B, Rahnama A. Leptospirosis in Golestan province in Iran (Reports of twelve cases). J Gorgan Uni Med Sci. 2007; 9(2): 76-80. [Persian]

30.Rafiei A, Hedayati Zadeh-Omran A, Babamahmoodi F, Alizadeh Navaei R, Valadan R. Review of Leptospirosis in Iran. J Mazandaran Univ Med Sci. 2012; 22(94): 114-25. [Persian]

31.Firouzi R, Vandyousefi J. A serological survey on bovine leptospirosis in Shiraz, Iran. J Vet Res. 2000; 1(2): 118-23.

32.Jafari SM, Vand Yousefi J, Azarvandi A. Evaluation of clinically suspected leptospirosis and identifying strains involved in bovine leptospira in the uromia city. Pajouhesh va Sazandeghi. 1997; 34: 120-2. [Persian]

33.Soltani Majd N, Darian EK, Khaki P, Bidhendi SM, Yahaghi E, Mirnejad R. Epidemiological patterns of Leptospira spp. among slaughterhouse workers in Zanjan-Iran. Asian Pac J Trop Dis.2012; 2: S550-2. doi:10.1016/s2222-1808(12)60218-7.

34.Khaki P, Roohi Z, Moradi Bidhendi S. Application of micro agglutination test in detecting serovars of leptospira. J Gorgan Uni Med Sci. 2014; 16(3): 99-105. [Persian]

35.Garooci Talebkhan M, Vandeyusefy J, Famileghadakchi H, Norouzian A. Seroepidemiology leptospiral contamination in dairy cattle farms around Mashhad staff. J Vet Res. 2003; 58(1): 89-94.

36.Bajani MD, Ashford DA, Bragg SL, Woods CW, Aye T, Spiegel RA, et al. Evaluation of four commercially available rapid serologic tests for diagnosis of leptospirosis. J Clin Microbiol. 2003; 41(2): 803-9. doi:10.1128/jcm.41.2.803809.2003.

37.Babakhani S, Maleki S, Baharvand M, Abdollahpour G. A study of serum outbreak of infection with various serovars of Leptospira among rice farmers of Visan in the Lorestan province. Sci Res Quar Period Lorestan Med Sci Univ. 2016; 18(2): 29 - 37. [Persian]

38.Abdollahpour G, Ramin A, Sanajou D. Seroinvestigation of buffaloes leptospirosis in Urmia district. Pub livestock Sci Res. 2016; 26(2): 59 -68. [Persian]

39.Honarmand HR, Mansour Ghanaei F, Heidarzadeh A, Asmar M. Isolation and Serotyping of endemic leptospires of eastern part of flat area of Guilan province, Iran. J Gorgan Uni Med Sci. 2009; 11(3): 53-9. [Persian]

40.Halliday JEB, Knobel DL, Allan KJ, de CBBM, Handel I, Agwanda B, et al. Urban leptospirosis in Africa: A crosssectional survey of Leptospira infection in rodents in the Kibera urban settlement, Nairobi, Kenya. Am J Trop Med Hyg. 2013; 89(6): 1095-102. doi:10.4269/ajtmh.13-0415.

41.Adler B, Faine S, Christopher WL, Chappel RJ. Development of an improved selective medium for isolation of leptospires from clinical material. Vet Microbiol. 1986; 12(4): 377-81. doi:10.1016/0378-1135(86)90087-8.

42.Vijayachari P, Sugunan AP, Umapathi T, Sehgal SC. Evaluation of darkground microscopy as a rapid diagnostic procedure in leptospirosis. Indian J Med Res. 2001; 114: 54-8.

43.Mandell GL, Bennett JE, Dolin R. Mandell, douglas and bennett's principle and practice of infectious diseases. $6^{\text {th }} \mathrm{ed}$. Philadelphia, USA: Elsevier Churchill Livingstone; 2005.

44.World Health Organization. Human leptospirosis: guidance for diagnosis, surveillance, and control. Geneva, Switzerland. 2003. 
45.Rostampour Yasouri S, Ghane M. A comparison between culture and PCR technique order to isolate and identify part of Leptospira spp. from environmental samples in the northern Iran. Eur J Exp Biol. 2014; 4(3): 606-11.

46.Saengjaruk P, Chaicumpa W, Watt G, Bunyaraksyotin G, Wuthiekanun V, Tapchaisri P, et al. Diagnosis of human leptospirosis by monoclonal antibody-based antigen detection in urine. J Clin Microbiol. 2002; 40(2): 480-9. doi:10.1128/jcm.40.3.480-489.2002.

47.Ahmad SN, Shah S, Ahmad FM. Laboratory diagnosis of leptospirosis. J Postgrad Med. 2005;51(3):195-200.

48.Smits HL, Eapen CK, Sugathan S, Kuriakose M, Gasem MH, Yersin C, et al. Lateral-flow assay for rapid serodiagnosis of human leptospirosis. Clin Diagn Lab Immunol. 2001; 8(1): 1669. doi:10.1128/CDLI.8.1.166-169.2001.

49.Richaud C, Margarita D, Baranton G, Saint Girons I. Cloning of genes required for amino acid biosynthesis from Leptospira interrogans serovar icterohaemorrhagiae. J Gen Microbiol. 1990; 136(4): 651-6. doi:10.1099/00221287-136-4-651.

50.Adler B, Murphy AM, Locarnini SA, Faine S. Detection of specific anti-leptospiral immunoglobulins $M$ and $G$ in human serum by solid-phase enzyme-linked immunosorbent assay. J Clin Microbiol. 1980; 11(5): 452-7. doi: 10.1128/JCM.11.5.452457.1980.

51.Dey S, Mohan CM, Ramadass P, Nachimuthu K. Diagnosis of leptospirosis by recombinant antigen based single serum dilution ELISA. Indian J Med Res. 2008; 128(2): 172-7.

52.Villumsen S, Pedersen R, Krogfelt KA, Jensen JS. Expanding the diagnostic use of PCR in leptospirosis: Improved method for DNA extraction from blood cultures. PLoS One. 2010; 5(8): e12095. doi:10.1371/journal.pone.0012095.

53. Vijayachari P, Sehgal SC. Recent advances in the laboratory diagnosis of leptospirosis and characterisation of leptospires. Indian J Med Microbiol. 2006; 24(4): 320-2. doi:10.4103/02550857.29408 .

54.Kositanont U, Rugsasuk S, Leelaporn A, Phulsuksombati D, Tantitanawat S, Naigowit P. Detection and differentiation between pathogenic and saprophytic Leptospira spp. by multiplex polymerase chain reaction. Diagn Microbiol Infect Dis. 2007; 57(2): 117-22. doi:10.1016/j.diagmicrobio.2006.07.014.

55.Ahmed A, Engelberts MF, Boer KR, Ahmed N, Hartskeerl RA. Development and validation of a real-time PCR for detection of pathogenic leptospira species in clinical materials. PLoS One. 2009; doi:10.1371/journal.pone.0007093.

56.Mori Y, Notomi T. Loop-mediated isothermal amplification $(L A M P):$ A rapid, accurate, and cost-effective diagnostic method for infectious diseases. $\mathrm{J}$ Infect Chemother. 2009;15(2):62-9. doi:10.1007/s10156-009-0669-9.
57.Toyokawa T, Ohnishi M, Koizumi N. Diagnosis of acute leptospirosis. Expert Rev Anti Infect Ther. 2011; 9(1): 111-21. doi:10.1586/eri.10.151.

58.Goris MG, Hartskeerl RA. Leptospirosis serodiagnosis by the microscopic agglutination test. Curr Protoc Microbiol. 2014; 32:Unit 12E 5. doi:10.1002/9780471729259.mc12e05s32.

59.Wong-Ekkabut J, Chadsuthi S, Triampo W, Doungchawee G, Triampo D, Krittanai C. Leptospirosis research: Response of pathogenic spirochete to ultaviolet-A irradiation. Afr JBiotechnol. 2009; 8(14): 3341-52.

60. Yasouri SR, Moghadam RG, Ghane M. Identification of pathogenic and saprophytic leptospira spp from the rice fields of Tonekabon township using PCR technique. Adv Stud Biol. 2013; 5: 437-45. doi:10.12988/asb.2013.3830.

61.Ciceroni L, Stepan E, Pinto A, Pizzocaro P, Dettori G, Franzin L, et al. Epidemiological trend of human leptospirosis in Italy between 1994 and 1996. Eur J Epidemiol. 2000; 16(1): 7986. doi:10.1023/a:1007658607963.

62. Vahedi Noori N, Vandyousefi J, Khorsand N. A study of incidence of Leptospira interrogans antibodies in the suspicious cow flocks Mazandaran province. Res Constr. 2002; 15(1): 135. [Persian]

63.Ebrahimi A, Alijani L, Abdollahpour GR. Serological survey of human leptospirosis in tribal area of West Central Iran. Iran J Med Sci. 2003; 28(2): 93-5.

64.Natarajaseenivasan K, Ratnam S. Seroprevalence of leptospiral infection in an agricultural based village in Tamil Nadu. Cheiron. 1997; 26: 80-3.

65.Ko AI, Reis MG, Dourado CMR, Johnson WD, Riley LW. Urban epidemic of severe leptospirosis in Brazil. Salvador Leptospirosis Study Group. Lancet. 1999; 354(9181): 820-5. doi: 10.1016/s0140-6736(99)80012-9.

66.Fakheri H, Makhlough A, Kashi Z. Acute pancreatitis in severe leptospirosis infection. J Mazandaran Univ Med Sci. 2008; 18(66): 92-7. [Persian]

67.Plank R, Dean D. Overview of the epidemiology, microbiology, and pathogenesis of Leptospira spp. in humans. Microbes Infect. 2000; 2(10): 1265-76. doi:10.1016/S12864579(00)01280-6. Microbes Infect. 2000; 2(10): 1265-76.doi: 10.1016/s1286-4579(00)01280-6

68.Wald B, Kasper F. Harrison principle of internal medicne. $16^{\text {th }}$ ed. Braun Wald Funcimd. 2005; 988-91.

69.Zakeri S, Sepahian N, Afsharpad M, Esfandiari B, Ziapour P, Djadid ND. Molecular epidemiology of leptospirosis in northern Iran by nested polymerase chain reaction/restriction fragment length polymorphism and sequencing methods. Am J Trop Med Hyg. 2010;82(5):899-903. doi:10.4269/ajtmh.2010.09-0721.

\section{How to Cite:}

Rostampour Yasouri S, Ghane M, Doudi M,Rezaei A,Sadat Naghavi N. [A Study of Leptospirosis Epidemiology in Iran and Diagnostic Techniques for Human, Livestock and Environment Samples]. mljgoums. 2020; 14(6): 1.9. DOI: 10.29252/mlj.14.6.1 